\title{
CONSTRUCTION OF THE WALI PITU'S SACREDNESS AND ISLAMIC VENERATION IN BALINESE HINDU CIVILIZATION
}

\author{
Amin Tohari ${ }^{*}$ \\ ${ }^{1}$ Universitas Islam Negeri Sunan Ampel Surabaya, East Java, Indonesia, email: amintoharininoke@gmail.com \\ *Corresponding Author

(C) 2021 by the authors. Submitted for possible open access publication under the terms and conditions of the Creative Commons
Attribution-ShareAlike 4.0 International License-(CC-BY-SA) (https://creativecommons.org/licenses/by-sa/4.0/)
do DOI: bttp://dx.doi.org/10.30983/islam realitas.v7i2.4722
\begin{tabular}{|l|c|c|}
\hline Submission: 31 August 2021 & Revised: 14 December 2021 & Published: 31 December 2021 \\
\hline
\end{tabular}

\begin{abstract}
This article explains the Wali Pitu (the seven saints) as a new form of veneration dynamics in Indonesia, which was built by the sacredness of Bali as the heart of Hindu culture in Indonesia. This phenomenon is unique and interesting, because the seven tombs of Muslim saints are venerated by Hindus of the region. This study uses a qualitative approach with the case-study method, extracting data as documentation from the notes of Toyyib Zaen Arifin during the expedition to search the seven graves, and interviews with members of the Manaqib al-Jamali, guidance, organizers and religious tourism congregations, as well as several caretakers of the tombs. This article describes the sacred construction of the discovery of the seven sainthoods tombs and their cults and their dynamics as a new form of the veneration of saints in Indonesia, one that differs from the other forms of veneration in Java which has been deeply rooted for a long time, such as the $W$ ali Songo (the nine saints).
\end{abstract}

Keywords: Sacred, Sainthood, Veneration, Balinese Muslim.

\begin{abstract}
Abstrak
Artikel ini berupaya menjelaskan W ali Pitu (tujuh wali) sebagai bentuk baru dinamika venerasi di Indonesia yang dibangun oleh sakralitas Bali sebagai jantung peradaban Hindu. Fenomena ini sangat unik dan menarik dimana kedua korpus yang diteliti sangat kontradiktif namun menjadi sebuah realitas nyata, dimana tujub makam wali Muslim ditemukan di Bali sebagai jantung peradaban Hindu. Menggunakan pendekatan kualitatif dengan metode studi kasus, penggalian data berupa dokumentasi dari hasil catatan Toyyib Zaen Arifin selama ekspedisi pencarian tujub makam wali, dan wawancara kepada anggota manaqib al-Jamali, pembimbing, penyelenggara dan jama'ah wisata religi, serta beberapa juru kunci makam Wali Pitu. Artikel ini menjelaskan konstruksi sakralitas atas penemuan tujuh makam wali dan pengkultusannya serta dinamikanya sebagai wujud baru venerasi orang suci di Indonesia yang berbeda dengan venerasi sebelumnya di Jawa yang sudah mengakar kuat sejak. lama (Wali Songo).
\end{abstract}

Kata Kunci: Sakralitas, Orang suci, Venerasi, Muslim Bali.

\section{Background}

In Indonesia, the veneration or worship of people who are sacred (wali) occurs through various historical intersections and crosses religious, cultural, and economic domains ${ }^{1}$, all three of which involve the community as construction subjects ${ }^{2}$. Veneration allows the cultural heritage protected by religious rituals to become sacred ${ }^{3}$. The example of venerating people who are considered sacred (wali) in Bali shows a different dimension to the worship of

${ }^{1}$ R. Setio, 'The Persistence of Ancestor Veneration: The Journal of North African Studies, 25.6 (2020), 995-1012 A Dialogical Relationship between Christianity and Indigenous Religions in Indonesia', Studies in Interreligious Dialogue, $\quad 29.2 \quad$ (2019), 220-26 $<$ https://doi.org/10.2143/SID.29.2.3287307>. <https://doi.org/10.1080/13629387.2019.1645013>.

3 J. Hellman, 'Living Together with Ancestors: Cultural Heritage and Sacred Places on West Java',

2 Souadou Lagdaf, 'Models of Sacredness: The International Journal of Religious Tourism and Pilgrimage, 5.1 (2017), 78-88.

Veneration of Walì's in the Tradition of Mauritanian Society', 
the wali in Java. This veneration practices in Bali has transcended religious and ethnic boundaries and has revealed the complexity of the relationship between the Hindu majority and the Muslim minority, making this phenomenon a trans-local issue. The phenomenon of saintveneration which is dominated by Java triggers to form of another pattern in other regions in the archipelago, because saints are considered to have mystical powers and are sacred. The Wali Pitu veneration in Bali shows another pattern of the sacred dimensions that have so far only been shaped by history and archaeological evidence.

The Muslim saints in Bali are known as Wali Pitu (the seven saints). This term harkens back to the nine Wali Songo in Java who are said to live from the 15th to 16th centuries. Unlike Wali Songo in Java, Wali Pitu was discovered by a local figure in Sidoarjo with his followers from a small al-Khoiriyah pesantren foundation in 1992. It was Toyyib Zaen Arifin who discovered the tombs of seven guardians during his spiritual journey in Bali. This article discusses the discourse on the sacredness of these contemporary Balinese Muslim guardians with a focus on the discovery and forms of veneration based on the cult of holiness and sacredness ${ }^{4}$. Borrowing the theory of locality in the cult of saints, Trofimova found that the practice of veneration is constructed from religious communication from religious leaders through their spiritual dream experiences and visions ${ }^{5}$. The case in Bali involves the concept of the locality of certain saints who are given extraordinary powers by God. The communities come to rely on their powers, which are further strengthened through stories developed in the community after their deaths.

The sacredness of Wali Pitu is formed through the sanctity of locality in local communities, which makes the face of 'Indonesian Islam' different from 'Arabic Islam' or 'Middle Eastern Islam'. The construction of the sacredness of Wali Pitu that was formed in a distinct manner from the saints in Java is a gap that this article seeks to fill. Scholars tend to focus on the more popular Wali Songo ${ }^{7}$. Second, this article identifies the veneration of Wali Pitu in a Hindu community, making this site even more unique to study, considering that Balinese Muslims are a minority.

This article uses a qualitative approach with a case-study methodology. Wali Pitu is a unique phenomenon that can be seen as a new alternative to veneration in Indonesia. This practice was shaped by the sacredness of Bali as the center of Indonesian Hindu culture. The data used in this study is primary data as documentation from the notes of Toyyib Zaen Arifin during an expedition to find the seven

\footnotetext{
${ }^{4}$ Georg Stauth and Samuli Schielke, Dimensions of Locality: Muslim Saints, Their Place and Space (London: transcript Verlag, 2008) $<$ https:/ /library.oapen.org/handle/20.500.12657/22534 $>$ [accessed 14 August 2021].

5 Ksenia Trofimova, "'Holiness" Constructed: Anonymous Saints in the Popular Traditions of Muslim Roma Communities in the Balkans', in The Revival of Islam in the Balkans: From Identity to Religiosity, ed. by Arolda Elbasani and Olivier Roy, The Islam and Nationalism Series (London: Palgrave Macmillan UK, 2015), pp. 163$81<$ https://doi.org/10.1057/9781137517845_9>.

6 'Abd Ar-Rahman Al-Bazzaz and Sylvia G. Haim, 'Islam and Arab Nationalism', Die Welt Des Islams, 3.3/4 (1954), 201-18 <https://doi.org/10.2307/1570165>; Christian C Sahner, 'The Making of the Medieval Middle East: Religion, Society, and Simple Believers, by Jack Tannous', The
}

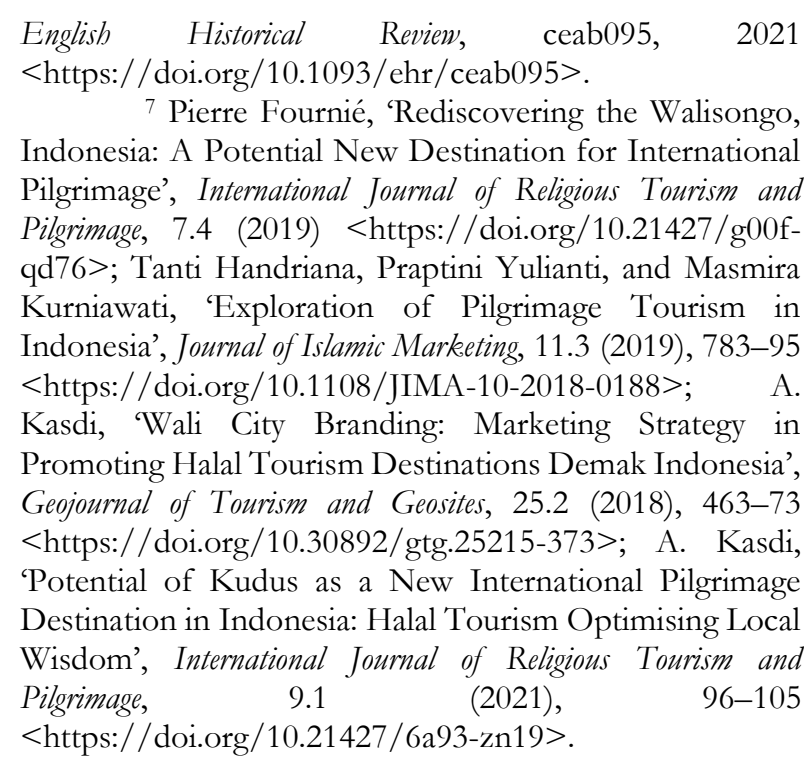


guardian graves in 1992. Researchers also used interview techniques for five members of Manaqib al-Jamali, mentors and organizers of religious tours to Wali Pitu, religious tourism congregations of Wali Pitu, and several caretakers of Wali Pitu's tomb. Secondary data are the research results published in Brill, Leiden and at SOAS, London ${ }^{8}$. These two studies served as our data reinforcement during preparing this manuscript. After the data was collected, it was analyzed by triangulation of sources by confirming the records of the expedition carried out by Toyyib Zaen Arifin and the research from Leiden and London, which is currently ongoing research on tracking the Yemeni Hadrami community in the Bali region.

\section{Islam at the Heart of Balinese Hindu Culture}

The existence of Islam in Bali is seen in an Islamic village. In contrast to Islam in Java, the history of Islam in Bali is very difficult to reconstruct because of the lack of scientific sources and archaeological evidence that has undergone research. The traditions that developed are only oral sources. The first information comes from the Majapahit kingdom in the mid-13th century. Oral history records that during the reign of Hayam Wuruk, about 40 Muslims from Majapahit, together with Dalem Ketut Nglesi (1380-14-60) founded a Gélgél mosque around 1380. It is not known exactly how Islam developed in Gélgél, but according to

${ }^{8}$ M. Slama, 'From Wali Songo to Wali Pitu: The Travelling of Islamic Saint Veneration to Bali', Between Harmony and Discrimination: Negotiating Religious Identities within Majority-Minority Relationships in Bali and Lombok, Query date: 2021-07-15 20:20:17, 2014, 112-43 <https://doi.org/10.1163/9789004271494_006>; H. Chambert-Loir, 'Saints and Ancestors: The Cult of Muslim Saints in Java', The Potent Dead: Ancestors, Saints and Heroes in Contemporary Indonesia, Query date: 2021-08-26 21:16:48, 2020, 132-40 < https://doi.org/10.4324/97810031181769>; V. Gottowik, 'Pilgrims, Prostitutes, and Ritual SeKs: Heterodox Ritual Practices in the Context of the Islamic Veneration of Saints in Central Java', Bijdragen Tot de Taal-, Land- En Volkenkunde, 174.4 (2018), 393-421 <https://doi.org/10.1163/22134379-17404001>;

Syaifudin Zuhri, 'Inventing Balinese Muslim Sainthood', Indonesia and the Malay World, 41.119 (2013), 1-13 <https://doi.org/10.1080/13639811.2012.750106>.
Ambary's findings, the ancestor of Balinese Muslim ancestors came from Gélgél ${ }^{9}$.

The second oral information comes from the well-known oral tradition is the Balinese Kidung Pemañcah which tells of some Muslims from Mecca who tried to influence Baturenggong, a Balinese king in the 15th century. The Muslims later formed a Muslim village in Klungkung, Karangasem Bali ${ }^{10}$. Another oral history is that there is a Muslim village called Kampung Wajo which was founded by the Muslim community from Loloan. The construction of the village was permitted by the ruler of Jembrana, namely I Gusti Ngurah Pancoran in $1670^{11}$. It is known that the Muslim from Mecca was Syarif Abdullah al-Qadri from Pontianak, who fled the Netherlands and was then stranded in Bali ${ }^{12}$.

Once again, oral traditions have created different versions and debate about the origin of Islam in Gélgél, Klungkung, and Loloan. However, Balinese Muslims come from a combination of Balinese-Hindu ancestors with Bugis, Javanese, Madurese, and Sasak in Lombok $^{13}$. In addition, Yemeni Hadrami descendants who call themselves sayyid is also alleged to have led to a Hindu-Balinese fusion with Islam-Arabic people because of their

9 Hasan Muarif Ambary, 'Mesjid Kampung Gelgel, Kabupaten Klungkung (Bali)', Archipel, 30.1 (1985), 39-41 <https://doi.org/10.3406/arch.1985.2238>.

${ }^{10}$ Mashino Ako and 増野亜子, 'Being MuslimBalinese : The Music and Identity of the Sasak Community in Eastern Bali' (National Museum of Ethnology, 2021) $<$ https://doi.org/10.15021/00009765> [accessed 27 August 2021]; Adrian Vickers, 'Hinduism and Islam in Indonesia: Bali and the Pasisir World', Indonesia, 44, 1987, 31-58 < https://doi.org/10.2307/3351220>.

11 Brigitta Hauser-Schäublin, "Bali Aga" and Islam: Ethnicity, Ritual Practice, and "Old-Balinese" as an Anthropological Construct', Indonesia, 77, 2004, 27-55.

12 Slama.

${ }^{13}$ Fredrik Barth, Ethnic Groups and Boundaries: The Social Organization of Culture Difference (Illinois: Waveland Press, 1998), p. 23. 
marriage to indigenous people who converted to Islam and had children in the Singaraja area ${ }^{14}$.

Regarding the history of Balinese Islam mentioned above, there is no oral information that links it to the existence of Wali Pitu. Wali Pitu was independently found in 1992 by a kyai (elder scholar) figure from Sidoarjo who then led him on an expedition to search for the seven guardian graves in Bali which personally had no connection with the figure. Naturally, Wali Pitu was unusual by this figure, which was allegedly different from the discovery of Wali Songo in Java.

Bali is known by the world as one of the most popular tourist destinations in the world ${ }^{15}$. Its cultural and natural diversity makes many local and foreign tourists flock to Bali ${ }^{16}$. Bali is also popularly known as the "Pulau Dewata" or "island of the Gods" because the majority of its people are Hindus ${ }^{17}$. Although the majority are Hindus, Bali is known as an area that has high religious tolerance, as evidenced by the many religions that are able to live side by side in one area without interreligious conflict ${ }^{18}$.
The existence of Wali Pitu in Bali is unique and contradictory, because the area is predominantly Hindu and the daily culture and traditions of the people are also Hindu customs. In contrast to Wali Songo, which was formed from the acculturation of Javanese culture with Islam, Bali remains an independent Hindu culture. Wali Pitu's efforts to promote Islam in the Island of the Gods face more difficulty than the Wali Song, because the existence of Wali Pitu was not naturally formed. The discovery of Wali Pitu was carried out by a "searching" process that began in 1992. The existence of Islamic villages such as Gélgél Village in Klungkung, Loloan Village in Jembrana, Pegayaman Village in Buleleng, and Kecicang Village in Karangasem is strong evidence that Islam in Bali was formed in a small community as a religious effort from the remnants of the history of Wali Pitu's existence.

\section{Discovery and Construction of the Sacred "Wali Pitu" in Bali}

In this sub-discussion, we discuss the discovery of Wali Pitu that was carried out on an expedition by Zain Toyyib Arifin and members
${ }^{14}$ Frode F. Jacobsen, Hadrami Arabs in Present-Day Indonesia: An Indonesia-Oriented Group with an Arab Signature (London: Routledge, 2008)

<https://doi.org/10.4324/9780203884614>.

15 I.M. Adhika, 'Reinvigorating Cultural Landscapes for Planning Cultural Tourism in Bali', Geojournal of Tourism and Geosites, 33.4 (2021), 1462-69 <https://doi.org/10.30892/gtg.334spl03-594>; I.K. Mastika, 'Destination Branding Model of an Ecological Tourism Village in Bali, Indonesia', Geojournal of Tourism and Geosites, $\quad 31.3 \quad$ (2020), $1068-74$ <https://doi.org/10.30892/gtg.31319-542>; $\quad$ K. Pamungkas, 'Geotourism Branding through the Names of Tourism Destinations in UNESCO Global Geopark Batur Bali: Morphological and Toponymic Studies', Geojournal of Tourism and Geosites, 31.3 (2020), 966-71 <https://doi.org/10.30892/gtg.31305-528>.

16 P. Dunbar-Hall, 'Culture, Tourism and Cultural Tourism: Boundaries and Frontiers in Performances of Balinese Music and Dance', Journal of Intercultural Studies, $22.2 \quad$ (2001), 173-87 <https://doi.org/10.1080/07256860120069594>; P. P. McKean, 'Tourism, Culture Change, and Culture Conservation in Bali', Changing Identities in Modern Southeast Asia, Query date: 2020-10-20 14:55:16, 2011, 237-48 <https://doi.org/10.1515/9783110809930.237>; M.
Picard, 'Balinese Identity as Tourist Attraction: From "Cultural Tourism" (Pariwisata Budaya) to "Bali Erect" (Ajeg Bali)', Tourist Studies, 8.2 (2008), 155-73 <https://doi.org/10.1177/1468797608099246>.

17 I Wayan Dibia, 'Odalan of Hindu Bali: A Religious Festival, a Social Occasion, and a Theatrical Event', Asian Theatre Journal, 2.1 (1985), 61-65 <https://doi.org/10.2307/1124507>.

18 I.G.P. Bagus Suka Arjawa, 'The Social Integration of Hindu and Muslim Communities: The Practice of $m$ menyama-Brayam in Contemporary Bali', Studia Islamika, $28.1 \quad$ (2021), $149-78$ <https://doi.org/10.36712/sdi.v28i1.10914>; Lene Pedersen, 6 Keeping the Peace: Interdependence and Narratives of Tolerance in Hindu-Muslim Relationships in Eastern Bali, Between Harmony and Discrimination: Negotiating Religious Identities within Majority-Minority Relationships in Bali and Lombok (Leiden, The Netherlands: Brill, 2014), pp. 165-96 <https://doi.org/10.1163/9789004271494_008>; Amin Tohari and Moch Khafidz Fuad Raya, 'The Meaning of Religious Moderation on the Resilience of Muslim Minority in Balinese Hindus', Journal of Contemporary Islam and Muslim Societies, 5.1 (2021), 77-103 <https://doi.org/10.30821/jcims.v5i1.8686>. 
of Manaqib al-Jamali. The data was obtained from the records of the expedition and interviews with the caretakers of the seven tombs.

The existence of Wali Pitu was controversial because it was considered a dilemma, both in terms of its discovery and location. The discovery of the site of the tomb of the seven saints by some traditionalist groups has been considered to work in the favor of the discoverer's fame, while others consider the method of finding the seven sites to be sought under religious interests. Meanwhile, the existence of the Wali Pitu site is unrepresentative in describing the sacred figures of an area. Such isTrofimova's theory of locality in the cult of saints. Bali is the heart of Hindu civilization where most of the Balinese population is Hindu (83.5\% or around 3.3 million people), while Muslims are a minority population which only amounts to $13.3 \%{ }^{19}$.

Wali Pitu is a new tomb site that is sacred by the Muslim community and its sacredness is also recognized by some Hindus around the tomb. Finding Wali Pitu is unique, because it used a new method in the ancient Islamic tradition called hätif, unlike the existence of Wali Songo in Java, which was proven by history and archaeological evidence ${ }^{20}$. The discovery of the seven sainthoods tombs with this method is very interesting, especially because it is far from Islamic culture and was nicknamed "the land of the infidels" by terrorists who made Bali a tanah jihad or land of jihad during the Bali Bombing tragedy (12 October 2002 and 1 October 2005) ${ }^{21}$. The existence of Wali Pitu was not naturally formed like Wali Songo. Wali Pitu's discovery

19 Badan Pusat Statistik Provinsi Bali, Penduduk. Provinsi Bali Menurut Agama Yang Dianut Hasil Sensus Penduduk 2010 (Bali: Badan Pusat Statistik Provinsi Bali, Pebruari 2018), p. 32.

${ }^{20}$ Abdul Wahid Hasyim, 'Demak Sultanate: The Fortress of Islamic Greatness in the Middle Ages Java Island', Buletin Al-Turas, 27.1 (2021), 1-16 <https://doi.org/10.15408/bat.v27i1.16400>.

21 Mirra Noor Milla, Faturochman, and Djamaludin Ancok, 'The Impact of Leader-Follower was carried out by a "search" process that began in 1992. The person who started the expedition to search for the seven guardian graves was Toyyib Zaen Arifin, a "village kyai" from Sidoarjo, East Java. Early on, Arifin knew Bali because he founded a small dhikr (remembrance of God) association that year named Manaqib alJamali. This dhikr gathering was initially only attended by a few of his followers from Sidoarjo and Gresik, but over time it was attended by hundreds of people from Madura and Bali. It was called "al-Jamali" because it was meant to open brotherhood between Muslims from Java, Madura, and Bali through assemblies of dhikr.

After Arifin founded Manaqib al-Jamali, a big incident happened to him. He apparently received whisperings or suggestions from the spiritual realm, which is termed bätif. In the Islamic tradition, hätif is a whisper that comes down to someone as a blessing from God and as a guide for the recipient ${ }^{22}$. In contrast to revelation (waby) and inspiration(ilhäm), hätif is received by a chosen person in a conscious state as a soft whispering voice from an unseen and undetectable source. Meanwhile, revelation is a message from God given to a chosen Prophet and Apostle as a guide to be distributed to mankind, such as the Quran, which was given to the Prophet Muhammad PBUH as the seal of the Prophets (al-khatam al-anbiyà). Hätif and ilhäm are both instructions from God given to people who are not prophets and apostles, but ordinary people. In contrast to hatitif the way of conveying ilham is through dreams or thought trajectories that accidentally appear in one's mind ${ }^{23}$. From this, it can be concluded that hatif and ilhäm are two forms of God's message given to ordinary

Interactions on the Radicalization of Terrorists: A Case Study of the Bali Bombers', Asian Journal of Social Psychology, 16.2 (2013), 92-100 <https://doi.org/10.1111/ajsp.12007>

22 T. Fahd, 'Hatif' (EI2, 1971).

${ }^{23}$ D.B. MacDonald, Thām' In The Encyclopaedia of Islam 2nd Ed. (Leiden: Brill, 1986), III; Mikhail Pelevin, 'The Inception of Literary Criticism in Early Modern Pashto Writings', Iranian Studies, 54.5-6 (2021), 947-76 <https://doi.org/10.1080/00210862.2020.1829461>. 
people, not prophets. But to determine whether a person had received hätif or ilham is not a simple matter. Traditionalists regard bätif and ilhām as sacred messages sent by God to the elect. Meanwhile, modernists are skeptical of their truth, considering them to be irrational believes that lead to acts of associating partners with God or polytheism (syirk).

Arifin is said to received a bätifin which he was ordered by God to search for the seven tombs of saints (wali) in different places. The bätif whisper that Arifin received was in boso jowo (Javanese language) which he heard almost every night for three days in a row in 1992:

1. "In telata Bali iku kawengku makam pitu piro wali cubo wujudno!" [in the land of Bali there are Seven Muslim Sainthoods. Try to find them! ]

2. "Ono sawijining pepunden dumunung ono ing telatah susunanging siti sasandingan pamujaan agung kang manggon sak duwuring tirto kang kadarbeni dining suwitaning pandito ojo sumelang!" [there is a pepunden shrine in a place on a mound above the water beside a Hindu temple guarded by a faithful priest, so do not hesitate!]

3. "Waspadakno pitu iku keparang dadi papat" [notice, the seven are divided into four]

4. "Pitu iku keparang dadi papat iku pengertenane: kapisan wus kaporo nyoto, kapindo istidroj wujude kembar, kaping telu wus lair naning durung wujud, kaping papat liyo bongso" [the seven saints are divided into four: the first has existed for a long time, the second is highly respected and are twins, the third has been born but has not yet seen his guardianship, and the fourth is from abroad]

The first tomb identified as Wali Pitu is the tomb of Mas Sepuh which is also known as the Makam Keramat Pantai Seseh, in Mengwi, Badung Bali. This tomb was discovered by Arifin in 1992 when one member of Manaqib al-Jamali was looking for information to the public about a tomb that was sacred but not widely known by the public. Arifin and members of al-Jamali found two other tombs, namely the tomb of Ratu Ayu Anak Agung Rai or better known as Dewi Khotijah and Sosrodiningrat. However, Arifin told members of the congregation that the two graves were not wali, as confirmed by another bātif he received.

According to the caretaker of the tomb (juru kunci), Mas Sepuh was one prince of the Mengwi kingdom in 1711. Mas Sepuh is of Javanese descent from his Muslim mother, while his father is from Blambangan who Hindu is. When raised by his mother, Mas Sepuh did not know that his father was the king of Mengwi. After growing up, he was told by his mother to find his father in Bali by riding a klepu or a kind of big fish with the head of a lion. Shortly after meeting his father, Mas Sepuh was confronted by a group of hostile people who wanted to kill him. Mas Sepuh then took out a keris (ceremonial knife) weapon and raised it to the sky. Suddenly the keris emitted a light that killed and injured the hostile group. This power is believed to embody the sanctity of Mas Sepuh.

The second tomb believed to be Wali Pitu is the tomb of Sheikh Yusuf al-Maghribi. Information on this saint was found from a prominent kyai in Tabanan Bali. Arifin searched for this information with the help of members of al-Jamali and he met KH. Nur Hadi. The sacredness of this second tomb occurred when the community wanted to build a tomb that had been damaged by the weather, but the authorities did not allow it, resulting in him (Arifin) falling ill. The community then asked the head of the natural and animal realm to allow them to build the tomb. After being allowed, he recovered from illness. This is then believed by the public as a proof for the sanctity of Sheikh Yusuf alMaghribi. Thus his tomb is known as the Makam Keramat Bedugul.

The third tomb, which is believed to be another Wali Pitu, was found by Arifin based on the hatif he received that revealed that the tomb of the next wali is in a public cemetery in the Karangasem area. Based on the instructions from 
the hatif that Arifin received, the figure buried in the tomb came from Hadhramaut Yemen named Habib Ali bin Abu Bakr al-Hamid, or better known as Habib Ali al-Hamid. Based on the title of habib, this third saint was a descendant of the Prophet Muhammad PBUH who is believed to have been a respected teacher at the Klungkung palace and taught the Malay language. It is not known exactly when Habib Ali al-Hamid became a Malay teacher, but according to the caretaker of the tomb, it is estimated that he lived during the reign of the Balinese King Dewa Agung Jambe I who was famous for his wisdom (circa 16861722). An oral story that exhibits the sanctity of Habib Ali al-Hamid recounts the malice of a prince, who were not happy with the existence of the Habib and intended to conspire against him. The prince asked his father (the King) to execute Habib Ali al-Hamid, but because of the King's love for Habib Ali al-Hamid, the King secretly ordered Habib Ali al-Hamid to leave the royal palace. However, shortly after arriving in Kusamba, Habib Ali al-Hamid was attacked by an unknown group of people (presumably an order from a prince) and he was killed. On the night of the murder of Habib Ali al-Hamid, suddenly fire emerged from the Habib's grave and killed the killers. The community then believed that the tomb of Habib Ali al-Hamid was sacred, so his tomb was popularly known as the Makam Keramat Kusambeh.

After several years, precisely in 1995, Arifin again carried out an expedition to find the tomb of the fourth and fifth saints. His meeting with Ghufron (a participant of manaqib al-Jamali from Bali) gave information that there was a tomb of a figure named Habib Ali Zainal Abidin al-Idrus. It turned out that Habib Ali's son alIdrus was still there. Then Arifin invited the alJamali congregation to meet his son, Habib Muhdor. It was through Habib Muhdor that Arifin got information on the tomb of Habib Ali al-Idrus. However, there is another unnamed tomb beside the tomb of Habib Ali al-Idrus which is estimated to be over 400 years older.
Besides the tomb, there the bricks surrounding the tomb are believed to have magical powers that can protect the tomb from damage caused by the eruption of Mount Agung in 1963. Arifin and Habib Muhdor then sought information on who was in the tomb, including by an oracle. After that, it was known that the tomb was a saint of Iraqi descent named Maulana Yusuf alBaghdadi. Since then, the tomb of Habib Ali alIdrus and the tomb of Maulana Yusuf alBaghdadi are known as the Twin Sacred Tombs, because these two tombs are interconnected. After that, it was identified that Habib Ali alIdrus was a tomb keeper (pandito) of Maulana Yusuf al-Baghdadi, according to bätif information received by Arifin.

The sixth tomb, which is believed to be one of the Wali Pitu is based on the hätif received by Arifin, which showed him a tomb in Buleleng. This time Arifin was accompanied by Habib Muhdor and Habib Muhammad on a sixth tomb search expedition. Arifin and his entourage found the tomb of a sainthood in a Chinese cemetery. The tomb is known as Kwan Lie or Sykeh Abdul Qodir Muhammad. According to a circulating story, Kwan Lie was one of three bodyguards assigned by Hong $\mathrm{Zi}$, an emperor in the Ming Dynasty (1470-1505) to accompany his daughter Ong Tien on a trip to Java to meet Sunan Gunung Djati, because Ong Tien fell in love with the king. Sunan and he married in 1481. Four years later, Ong Tien died and was buried next to Sunan Gunung Djati's grave.

Back to Kwan Lie, he was a disciple of Sunan Gunung Djati. When Ong Tien became Sunan's wife, Kwan Lie converted to Islam and helped spread Islam with Sunan Gunung Djati. It is not known for certain why Kwan Lie's tomb is in Buleleng and reached the land of Bali. The lack of oral history information leads to the obfuscation of this detail. However, Arifin reiterated based on the accepted oracle and hatif that Kwan Lie is the sixth saint.

The last tomb identified as the seventh wali is the tomb of a Hadhrami descendant who holds 
the title habib. However, unlike the other six saints, this seventh saint has not died. Arifin has known about him qobla al-wujud (before his appearance) through the batif he received. Based on information from Arifin, the last guardian's tombs is located the Loloan Jembrana area, and Arifin and the al-Jamali congregation must wait for the saint's death. Arifin said that the seventh saint will be known after his death. Sure enough, on March 29, 1999, a habib named Habib Ali bin Abu Bakar Bafaqih or better known as Habib Ali Bafaqih, died. Unlike the previous saints who were sacred through supernatural events or events beyond reason, Habib Ali Bafaqih was known for his high religious knowledge so that the determination of the holiness of the seventh saint was based on the breadth of his religious knowledge.

With the discovery of the seven tombs of the Wali Pitu in Bali, finally Arifin and the AlJamali congregation have completed God's command for an expedition to find the seven holy people who was unknown to the public and whose guardianship was doubtful. The construction of sacredness for each of the seven saints is different according to the life experience of the saint in question and the special gifts given to them from God. However, from this it can be concluded that the Wali Pitu discovery expedition was carried out using the hatiff method, which was not used in the finding of the Wali Songo tombs in Java.

\section{Dynamics of the Veneration of Saints in Indonesia}

The veneration of people who are holy in Islam at their graves is called a pilgrimage (ziarah). However, the term pilgrimage is also not always identified with a ziarah. Chambert-Loir defined it as the practice of paying homage to parents and people who are sacred and have a certain sacredness ${ }^{24}$, which brings barokah or divine blessings ${ }^{25}$. In Indonesia, pilgrimages visit not only tombs but entails certain rituals such as prayers asking for good fortune and position. Prayers that are read during pilgrimage rituals have also transformed. In the past pilgrims only said prayers for themselves, now prayer rituals are equipped with hadiwan or prayers that are said to God through the intermediary of the saint's sacredness, manaqib or reading poems about the saints biography, and haul or anniversaries. This ritual method is the same as for holy people abroad such as pilgrimages to Sheikh Abdul alQadir al-Jailani, whose Sufi order has a strong presence in Indonesia and whose tomb is always crowded with visitors who want to get blessings ${ }^{26}$.

The phenomenon of veneration in Indonesia is influenced by the local culture. The wali pilgrimage is considered to be a source of the legitimacy of the Sufi credentials of a person or a certain group ${ }^{27}$. The peak of saint veneration in Java is that of Wali Songo ${ }^{28}$. Their graves and archaeological remains are decorated with local ornaments that combine the art of local Hindu, Chinese, and Arabic architects ${ }^{29}$. The appearance

27 Julian Millie, Splashed by the Saint: Ritual Reading and Islamic Sanctity in West Java (Leiden: KITLV-Press, 2009), p. 21.

${ }^{28}$ James J. Fox, review of Review of Nine Saints of Java, by D.A. Rinkes and others, Asian Journal of Social Science, 29.2 (2001), 345-47.

${ }^{29} \mathrm{~S}$. Anggraeni Dyah and Farhan Kahirillah Zein, 'The Influence of Cultural Acculturation on Architecture Keraton Kasepuhan Cirebon', in Reframing the Vernacular: Politics, Semiotics, and Representation, ed. by Gusti Ayu Made Suartika and Julie Nichols (Cham: Springer International Publishing, 2020), pp. 251-60 <https://doi.org/10.1007/978-3-030-22448-6_20>. 
of art in the saint's tomb persuades the public to sanctify the site which can bring blessings. The phenomenon of saint pilgrimage in Indonesia is always associated with blessing by consecrating tomb sites. Those who go believe they will receive blessings. Those who do not go and commit crimes during pilgrimages will fall to misfortune $e^{30}$.

Pilgrims believe that the guardian must be a firm believer who can guide mankind. Besides that, their origins from noble circles illustrates how respected they are. In other publications, some mention that their royal lineage came from Arabia and China, thus forming the so-called 'Sino-Javanese Muslims ${ }^{31}$. Currently, there are certain groups who consider the lineage of the saints and their ancestors to be from Hadhramaut, Yemen who migrated to Indonesia in large numbers until the 19th century ${ }^{32}$. They claim that the noble group who became the ruler of the archipelago, including the Wali Songo, were descendants of the Prophet Muhammad PBUH - what they called sayyid ${ }^{33}$.

Despite the debate over the lineage claims of the Wali Songo, the practice of veneration has increased during haul and maulid celebrations in recent decades ${ }^{34}$. This phenomenon brings new commodities. Fox has found active mobility in the collective practice of veneration ${ }^{35}$. When we were compiling this research, we met with Kyai Nasron Hakim, a mentor and organizer of a religious tour to Wali Songo, who said:

${ }^{30}$ James J. Fox, 'Ziarah Visits to the Tombs of the Wali, the Founders of Islam on Java', Islam in the Indonesian Social Context, 15, 1991, 19-31; Jamhari Jamhari, 'The Meaning Interpreted: The Concept of Barakah in Ziarah', Studia Islamika, $8.1 \quad$ (2001) <https://doi.org/10.15408/sdi.v8i1.696>.

${ }^{31}$ Sumanto Al Qurtuby, 'The Tao of Islam: Ceng Ho and the Legacy of Chinese Muslims in Pre-Modern Java', Studia Islamika, $16.1 \quad$ (2009) <https://doi.org/10.15408/sdi.v16i1.489>.

${ }^{32}$ Lodewijk Willem Christiaan van den Berg, Le Hadhramout et les colonies arabes dans l'archipel Indien (Batavia: Impr. du gouvernement, 1886).

${ }^{33}$ Berg.

34 Muhammad As'ad, 'The Dynamics of the Indonesian Hadramis on the Maulid Celebration', QIJIS
"Now it is common for the society or residents in a village to make a wali pilgrimage by renting one or more buses. They use personal money for transportation and all necessities during the pilgrimage. The more people who join the pilgrimage, the cheaper the cost. Usually, one bus is filled with 50-60 people. When the news spreads that a wali pilgrimage will be held, people flocked to invite their children, wives, and relatives. The society considers the wali's pilgrimage to bring blessings as fortune and safety". ${ }^{36}$

Fox said that this kind of tour is usually organized by people belonging to the largest Islamic mass organization in Indonesia, namely Nahdlatul 'Ulama' (NU). This mass organisation has many followers, especially in East Java, which makes the practice of veneration more entrenched and in demand by the public ${ }^{37}$. Statistical data from the East Java provincial government mentions that from 1998 (after the New Order regime collapsed) until 2005, the number of pilgrims of Wali SOngo sites increased from 500,000 people to approximately $4,000,000^{38}$. The post-New Order era opened "fresh air" for traditionalists. This gave rise to another wave of veneration as a pilgrimage revival in Indonesia. Seeing this movement, the administrators of the guardian's gravesites renovated the building and the grave area to make it easier for pilgrims. The renovation of tombs that are sacred is a sign that veneration is

(Qudus International Journal of Islamic Studies), 8.2 (2020), 389$430<$ https://doi.org/10.21043/qijis.v8i2.6586>; Tommy Christomy, 'Signs of the Wali: Narratives at the Sacred Sites in Pamijahan, West Java', ANU Press, 2003 <https://doi.org/10.25911/5d51573a0523f>.

${ }^{35}$ Fox, 'Review of Nine Saints of Java'.

${ }^{36}$ Nasron Hakim, Wisata Religi Wali Pitu Bali,

2019.

37 James J. Fox, 'Interpreting the Historical Significance of Tombs and Chronicles in Contemporary Java, in The Potent Dead (Milton Park, UK: Routledge, 2002).

${ }^{38}$ George Quinn, 'Local Pilgrimage in Java and Madura: Why Is It Booming?’, IIAS Newsletter, 35.November (2004), 16. 
rising $^{39}$. Doorn-Harder \& Jong regard the phenomenon of the revival of veneration as a political effort to strengthen the regime by getting ideological support from the traditionalists ${ }^{40}$.

The increasing popularity of veneration was then picked up by the Indonesian government through the Ministry of Tourism, which highlighted the development of religious tourism as a new form of tourism that was officially introduced to the public ${ }^{41}$. This project examines sites that are sacred and worthy of pilgrimage in six provinces in Indonesia, including the accessibility of transportation and infrastructure. Directly, this project invites the business potential for the surrounding community and strengthens local products that promote the unique traditions and culture of each wali who come to spread the religion of Islam $^{42}$.

The practice of veneration in Indonesia has undergone a transformation from being motivated by sacredness and spirituality to being motivated by economic interest where the concept of sacredness has become a new commodity at the intersection between religion and materialism. Quinn commented: "The practice of veneration in a wali's pilgrimage site should be free from the word money, but in reality veneration is a transactional-supernatural practice that continues to grow" 43. Thus, veneration is a transformative religious expression, starting from sacredness and becoming economic commodities.

\section{Conclusion}

In the Islamic world, saint veneration is an important religious tradition as a tribute to religious figures who are considered sacred and who have their links to God and the Prophet Muhammad PBUH. The saints are not only sacred but also respected because they are chosen human beings with esoteric powers as blessings. The discovery of Wali Pitu is a new form of veneration in Indonesia constructed by the sacredness of Bali, which is a bastion of Hindu culture. This phenomenon is very contradictory and unique, because Muslim saint veneration emerged in a majority Hindu population. The discovery process involves a transcendental narrative of spirituality, tracing the lineage of Wali Songo, elite nobles as descendants of the Prophet Muhammad PBUH, and the construction of sacredness attached to each Balinese Muslim guardian. Hätif as a new discovery method accepted by Toyyib Zaen Arifin plays a key role in the construction this sacredness of the holy people of Bali. The dimension of sacredness is formed to create a new form of the veneration of saints in Indonesia, which differs from the previous veneration practices in Java, which has been deeply rooted for a long time, namely the veneration of Wali Songo.

\section{References}

Adhika, I.M., 'Reinvigorating Cultural Landscapes for Planning Cultural Tourism in Bali', Geojournal of Tourism and Geosites, $33.4 \quad$ (2021), 1462-69

Wisata Religi (Jakarta: Departmen Kebudayaan dan Parawisata, 2006).

42 Rizal Akbar Aldyan, 'The Commodification of Religious Tourism in the Tomb of Sunan Kudus', Cultural Tourism Research, 2.7 (2020), 32-47 <https://doi.org/10.5281/zenodo.3692897>; Fournié.

43 George Quinn, 4. Throwing Money at the Holy Door: Commercial Aspects of Popular Pilgrimage in Java, Expressing Islam (Singapore: ISEAS Publishing, 2008), pp. 63-79

$<$ https://www.degruyter.com/document/doi/10.1355/9 789812308528-008/html> [accessed 29 August 2021]. 
$<$ https://doi.org/10.30892/gtg.334spl0 3-594>

Ako, Mashino, and 増野亜子, 'Being MuslimBalinese: The Music and Identity of the Sasak Community in Eastern Bali' (National Museum of Ethnology, 2021) <https://doi.org/10.15021/00009765> [accessed 27 August 2021]

Alatas, Ismail Fajrie, 'Digital Theology: Saintly Marvels and God-Talk on Facebook', CyberOrient, $15.1 \quad$ (2021), 33-58 <https://doi.org/10.1002/cyo2.6>

Al-Bazzaz, 'Abd Ar-Rahman, and Sylvia G. Haim, 'Islam and Arab Nationalism', Die Welt Des Islams, 3.3/4 (1954), 201-18 <https://doi.org/10.2307/1570165>

Aldyan, Rizal Akbar, 'The Commodification of Religious Tourism in the Tomb of Sunan Kudus', Cultural Tourism Research, 2.7 (2020), 32-47 $<$ https://doi.org/10.5281/zenodo.3692 $897>$

Ambary, Hasan Muarif, 'Mesjid Kampung Gelgel, Kabupaten Klungkung (Bali)', Archipel, $30.1 \quad$ (1985), 39-41 <https://doi.org/10.3406/arch.1985.22 $38>$

Anggraeni Dyah, S., and Farhan Kahirillah Zein, 'The Influence of Cultural Acculturation on Architecture Keraton Kasepuhan Cirebon', in Reframing the Vernacular: Politics, Semiotics, and Representation, ed. by Gusti Ayu Made Suartika and Julie Nichols (Cham: Springer International Publishing, 2020), pp. 251-60 <https://doi.org/10.1007/978-3-03022448-6_20>

Arjawa, I.G.P. Bagus Suka, 'The Social Integration of Hindu and Muslim Communities: The Practice of ummenyama-Brayaws in Contemporary Bali', Studia Islamika, 28.1 (2021), 149-78 $<$ https://doi.org/10.36712/sdi.v28i1.10 914>

As'ad, Muhammad, 'The Dynamics of the Indonesian Hadramis on the Maulid Celebration', QIJIS (Qudus International Journal of Islamic Studies), 8.2 (2020), 389-
430

<https://doi.org/10.21043/qijis.v8i2.65 $86>$

Badan Pusat Statistik Provinsi Bali, Penduduk Provinsi Bali Menurut Agama Yang Dianut Hasil Sensus Penduduk 2010 (Bali: Badan Pusat Statistik Provinsi Bali, Pebruari 2018)

Barth, Fredrik, Ethnic Groups and Boundaries: The Social Organization of Culture Difference (Illinois: Waveland Press, 1998)

Berg, Lodewijk Willem Christiaan van den, Le Hadhramout et les colonies arabes dans l'archipel Indien (Batavia: Impr. du gouvernement, 1886)

Bruinessen, Martin van, 'Shaykh 'Abd Al-Qadir al-Jilani and the Qadiriyya in Indonesia', Journal of the History of Sufism, 1.2 (2000), 361-95

Chambert-Loir, H., 'Saints and Ancestors: The Cult of Muslim Saints in Java', The Potent Dead: Ancestors, Saints and Heroes in Contemporary Indonesia, Query date: 202108-26 21:16:48, 2020, 132-40 <https://doi.org/10.4324/9781003118 176-9>

Chambert-Loir, Henri, 'Saints and Ancestors: The Cult of Muslim Saints in Java', in The Potent Dead (Routledge, 2002)

Christomy, Tommy, 'Signs of the Wali: Narratives at the Sacred Sites in Pamijahan, West Java', ANU Press, 2003 $<$ https://doi.org/10.25911/5d51573a0 $523 \mathrm{f}>$

Dibia, I Wayan, 'Odalan of Hindu Bali: A Religious Festival, a Social Occasion, and a Theatrical Event', Asian Theatre Journal, $2.1 \quad$ (1985), 61-65 $<$ https://doi.org/10.2307/1124507>

Doorn-Harder, Nelly Van, and Kees De Jong, 'The Pilgrimage to Tembayat: Tradition and Revival in Islamic Mysticism in Contemporary Indonesia', in The Blackwell Companion to Contemporary Islamic Thought (John Wiley \& Sons, Ltd, 2006), pp. 482-506 
<https://doi.org/10.1002/9780470996 188.ch29>

Dunbar-Hall, P., 'Culture, Tourism and Cultural Tourism: Boundaries and Frontiers in Performances of Balinese Music and Dance', Journal of Intercultural Studies, 22.2 (2001), $173-87$ $<$ https://doi.org/10.1080/0725686012 0069594>

Fahd, T., 'Hatif' (EI2, 1971)

Fournié, Pierre, 'Rediscovering the Walisongo, Indonesia: A Potential New Destination for International Pilgrimage', International Journal of Religious Tourism and Pilgrimage, 7.4 < https://doi.org/10.21427/g00f-qd76>

Fox, James J., 'Interpreting the Historical Significance of Tombs and Chronicles in Contemporary Java', in The Potent Dead (Milton Park, UK: Routledge, 2002)

, review of Review of Nine Saints of Java, by D.A. Rinkes, H.M. Froger, Alijah Gordon, and G.W.J. Drewes, Asian Journal of Social Science, 29.2 (2001), 34547

, 'Ziarah Visits to the Tombs of the Wali, the Founders of Islam on Java', Islam in the Indonesian Social Context, 15, 1991, 1931

Gottowik, V., 'Pilgrims, Prostitutes, and Ritual SeKs: Heterodox Ritual Practices in the Context of the Islamic Veneration of Saints in Central Java', Bijdragen Tot de Taal-, Land- En Volkenkunde, 174.4 (2018), 393-421 $<$ https://doi.org/10.1163/2213437917404001>

Hakim, Nasron, Wisata Religi Wali Pitu Bali, 2019

Handriana, Tanti, Praptini Yulianti, and Masmira Kurniawati, 'Exploration of Pilgrimage Tourism in Indonesia', Journal of Islamic Marketing, 11.3 (2019), 783-95 $<$ https://doi.org/10.1108/JIMA-102018-0188>

Hasyim, Abdul Wahid, 'Demak Sultanate: The Fortress of Islamic Greatness in the
Middle Ages Java Island', Buletin AlTuras, $27.1 \quad$ (2021), $1-16$ $<$ https://doi.org/10.15408/bat.v27i1.1 $6400>$

Hauser-Schäublin, Brigitta, "Bali Aga" and Islam: Ethnicity, Ritual Practice, and "Old-Balinese" as an Anthropological Construct', Indonesia, 77, 2004, 27-55

Hellman, J., 'Living Together with Ancestors: Cultural Heritage and Sacred Places on West Java', International Journal of Religious Tourism and Pilgrimage, 5.1 (2017), 78-88

Jacobsen, Frode F., Hadrami Arabs in Present-Day Indonesia: An Indonesia-Oriented Group with an Arab Signature (London: Routledge, 2008)

$<$ https://doi.org/10.4324/9780203884 614>

Jamhari, Jamhari, 'The Meaning Interpreted: The Concept of Barakah in Ziarah', Studia Islamika, $\quad 8.1 \quad$ (2001) <https://doi.org/10.15408/sdi.v8i1.696 $>$

Kasdi, A., 'Potential of Kudus as a New International Pilgrimage Destination in Indonesia: Halal Tourism Optimising Local Wisdom', International Journal of Religious Tourism and Pilgrimage, 9.1 (2021), 96-105 $<$ https://doi.org/10.21427/6a93zn19>

, 'Wali City Branding: Marketing Strategy in Promoting Halal Tourism Destinations Demak Indonesia', Geojournal of Tourism and Geosites, 25.2 (2018), 463-73 $<$ https://doi.org/10.30892/gtg.25215$373>$

Lagdaf, Souadou, 'Models of Sacredness: The Veneration of Wali's in the Tradition of Mauritanian Society', The Journal of North African Studies, 25.6 (2020), 995-1012 $<$ https://doi.org/10.1080/13629387.20 19.1645013>

MacDonald, D.B., Thäm' In The Encyclopaedia of Islam 2nd Ed. (Leiden: Brill, 1986), III 
Mastika, I.K., 'Destination Branding Model of an Ecological Tourism Village in Bali, Indonesia', Geojournal of Tourism and Geosites, $31.3 \quad$ (2020), 1068-74 <https://doi.org/10.30892/gtg.31319$542>$

McKean, P., 'Tourism, Culture Change, and Culture Conservation in Bali', Changing Identities in Modern Southeast Asia, Query date: 2020-10-20 14:55:16, 2011, 237-48 $<$ https://doi.org/10.1515/9783110809 930.237>

Milla, Mirra Noor, Faturochman, and Djamaludin Ancok, 'The Impact of Leader-Follower Interactions on the Radicalization of Terrorists: A Case Study of the Bali Bombers', Asian Journal of Social Psychology, 16.2 (2013), 92-100 <https://doi.org/10.1111/ajsp.12007>

Millie, Julian, Splashed by the Saint: Ritual Reading and Islamic Sanctity in West Java (Leiden: KITLV-Press, 2009)

Millie, Julian and Syihabuddin, 'Addendum to Drewes: The Burda of Al-Būsî̀ī and the Miracles of Abdulqadir al-Jaelani in West Java', Bijdragen Tot de Taal-, Land- En Volkenkunde, 161.1 (2005), 98-126

Pamungkas, K., 'Geotourism Branding through the Names of Tourism Destinations in UNESCO Global Geopark Batur Bali: Morphological and Toponymic Studies', Geojournal of Tourism and Geosites, 31.3 (2020), 966-71 $<$ https://doi.org/10.30892/gtg.31305$528>$

Pedersen, Lene, 6 Keeping the Peace: Interdependence and Narratives of Tolerance in Hindu-Muslim Relationships in Eastern Bali, Between Harmony and Discrimination: Negotiating Religious Identities within Majority-Minority Relationships in Bali and Lombok (Leiden, The Netherlands: Brill, 2014), pp. 16596

$<$ https://doi.org/10.1163/9789004271 494_008>

Pelevin, Mikhail, 'The Inception of Literary Criticism in Early Modern Pashto Writings', Iranian Studies, 54.5-6 (2021),
$947-76$

<https://doi.org/10.1080/00210862.20 20.1829461>

Picard, M., 'Balinese Identity as Tourist Attraction: From "Cultural Tourism" (Pariwisata Budaya) to "Bali Erect" (Ajeg Bali)', Tourist Studies, 8.2 (2008), 155-73 <https://doi.org/10.1177/1468797608 099246>

Pusat Penelitian dan Pengembangan Keparawisataan, Laporan Akbir: Penelitian Pengembangan Wisata Religi (Jakarta: Departmen Kebudayaan dan Parawisata, 2006)

Quinn, George, 4. Throwing Money at the Holy Door: Commercial Aspects of Popular Pilgrimage in Java, Expressing Islam (Singapore: ISEAS Publishing, 2008), pp. 63-79 $<$ https://www.degruyter.com/documen t/doi/10.1355/9789812308528-

008/html> [accessed 29 August 2021]

- 'Local Pilgrimage in Java and Madura: Why Is It Booming?', IIAS Newsletter, 35.November (2004), 16

Qurtuby, Sumanto Al, 'The Tao of Islam: Ceng Ho and the Legacy of Chinese Muslims in Pre-Modern Java', Studia Islamika, 16.1 (2009)

$<$ https://doi.org/10.15408/sdi.v16i1.48 9>

Sahner, Christian C, 'The Making of the Medieval Middle East: Religion, Society, and Simple Believers, by Jack Tannous', The English Historical Review, ceab095, 2021

<https://doi.org/10.1093/ehr/ceab095 $>$

Setio, R., 'The Persistence of Ancestor Veneration: A Dialogical Relationship between Christianity and Indigenous Religions in Indonesia', Studies in Interreligious Dialogue, 29.2 (2019), 220-26 $<$ https://doi.org/10.2143/SID.29.2.328 $7307>$

Slama, M., 'From Wali Songo to Wali Pitu: The Travelling of Islamic Saint Veneration to Bali', Between Harmony and Discrimination: Negotiating Religious Identities within 
Majority-Minority Relationships in Bali and Lombok, Query date: 2021-07-15 20:20:17, 2014, 112-43 $<$ https://doi.org/10.1163/9789004271 494_006>

Stauth, Georg, and Samuli Schielke, Dimensions of Locality: Muslim Saints, Their Place and Space (London: transcript Verlag, 2008) <https://library.oapen.org/handle/20.5 00.12657/22534> [accessed 14 August 2021]

Taragan, Hana, 'The Tomb of Sayyidnā 'Alī in Arșūf: The Story of a Holy Place', Journal of the Royal Asiatic Society, 14.2 (2004), 83102

<https://doi.org/10.1017/S135618630 4003682>

Tohari, Amin, and Moch Khafidz Fuad Raya, 'The Meaning of Religious Moderation on the Resilience of Muslim Minority in Balinese Hindus', Journal of Contemporary Islam and Muslim Societies, 5.1 (2021), 77103

<https://doi.org/10.30821/jcims.v5i1.8 686>
Trofimova, Ksenia, “Holiness” Constructed: Anonymous Saints in the Popular Traditions of Muslim Roma Communities in the Balkans', in The Revival of Islam in the Balkans: From Identity to Religiosity, ed. by Arolda Elbasani and Olivier Roy, The Islam and Nationalism Series (London: Palgrave Macmillan UK, 2015), pp. 163-81 $<$ https://doi.org/10.1057/9781137517 845_9>

Vickers, Adrian, 'Hinduism and Islam in Indonesia: Bali and the Pasisir World', Indonesia, 44, 1987, 31-58 $<$ https://doi.org/10.2307/3351220>

Von Denffer, Dietrich, 'Baraka as Basic Concept of Muslim Popular Belief, Islamic Studies, 15.3 (1976), 167-86

Zuhri, Syaifudin, 'Inventing Balinese Muslim Sainthood', Indonesia and the Malay World, 41.119 (2013), 1-13 $<$ https://doi.org/10.1080/13639811.20 12.750106> 